\title{
ORGANIZACJA I ZARZĄDZANIE FUNDUSZAMI CELOWYMI NA KULTURĘ - ANALIZA POLSKICH I HOLENDERSKICH DOŚWIADCZEŃ W ZAKRESIE FINANSOWANIA*
}

\begin{abstract}
Organization and management of special culture funds - an analysis of Polish and Dutch experiences in financing cultural activities
\end{abstract}

This article is a reflection on a project related to changes in the special financing of cultural activities in Poland. In the first part, the author refers to the native tradition of the application of special funds and on the examples of The Cultural Development Fund, The Creativity Promotion Fund and The Culture Promotion Fund, makes a critical analysis of their organization and management. Finally, to crystallize the set of good practices, Polish solutions have been confronted with the widely developed Dutch model of special founds dedicated to the culture.

Keywords: public funding, culture, special fund, Poland, the Netherlands

\section{Streszczenie}

Artykuł stanowi refleksję nad projektem zmian w zakresie celowego finansowania działalności kulturalnej w Polsce. W pierwszej części autor odnosi się do rodzimej tradycji funkcjonowania funduszy celowych i na przykładach Funduszu Rozwoju Kultury, Funduszu Promocji Twórczości oraz Funduszu Promocji Kultury dokonuje krytycznej analizy ich zorganizowania i zarządzania. Finalnie, aby wykrystalizować zestaw dobrych praktyk, polskie rozwiązania zostały skonfrontowane z rozwiniętym na szeroką skalę holenderskim modelem celowego wspierania kultury.

Słowa kluczowe: finansowanie publiczne, kultura, fundusz celowy, Polska, Holandia

* Artykuł powstał na podstawie III rozdziału pracy licencjackiej napisanej pod kierunkiem dr Joanny Szulborskiej-Łukaszewicz na Uniwersytecie Jagiellońskim w Krakowie, obronionej w 2015 roku. 


\section{Uwagi wstępne}

Państwowe fundusze celowe zostały wyodrębnione jako jeden z elementów tworzących sektor finansów publicznych (Dz.U. 2009, nr 157, poz. 1240 ze zm.)'. Zgodnie z definicją zaproponowaną przez Dorotę Ilczuk [2012: 43]: „Publiczny fundusz celowy to alternatywna do budżetu forma organizacyjna gromadzenia i wydatkowania środków publicznych pochodzących ze ściśle określonych źródeł i przeznaczonych na konkretny cel".

Początków polskiej tradycji finansowania celowego - w jej nowożytnym wydaniu - należy szukać już w okresie dwudziestolecia międzywojennego [Szołno-Koguc, 2007: 130-132]. Jeśli zaś chodzi o mechanizmy tego typu z przeznaczeniem na cele kulturalne, to szczególnie istotny jest tu okres PRL-u i funkcjonowania skorelowanych z konkretnymi dziedzinami sztuki licznych parabudżetów, takich jak - Fundusz Autorski (1964), Fundusz Rozwoju Twórczości Plastycznej (1972) czy Fundusz Kinematografii (1987), które w trybie deskryptywnym opisały Joanna Szulborska-Łukaszewicz [2009: 11-18] i Krystyna Kietlińska [1995: 91-106]. Gdy mówimy o perspektywie po-transformacyjnej, to temat celowego wspierania działań kulturalnych jest marginalizowany w monograficznych opracowaniach systemu finansowania kultury w Polsce [Barański, 2015], czy wręcz pomijany w całościowych analizach gospodarki funduszowej [Szołno-Koguc, 2007]. Za punkt odniesienia niniejszego artykułu przyjmuję więc reformatorskie propozycje Doroty Ilczuk i Wojciecha Misiaga [2003] oraz zalecenia zawarte w dokumencie Tezy Funduszu Promocji Twórczości poszukiwanie alternatywnych źródet finansowania [2013].

Tekst ma charakter teoretyczny i opiera się na analizie wybranych wątków z rodzimej tradycji finansowania parabudżetowego oraz komplementarnej do niej refleksji nad rozwiniętym systemem celowego wspierania kultury, który funkcjonuje w Holandii. Celem tak skonstruowanej metodologii jest krytyczne spojrzenie na mechanizmy organizacji i zarządzania funduszami celowymi na kulturę w Polsce.

\section{Fundusz Rozwoju Kultury}

Wśród mechanizmów celowych funkcjonujących w okresie PRL-u najistotniejsze znaczenie należy przypisać otwartemu w 1982 roku Funduszowi Rozwoju Kultury (Dz.U. 1982, nr 14, poz. 111 ze zm.)². Instrument ten powstał, aby

${ }^{1}$ Każdy fundusz celowy musi być tworzony na podstawie odrębnej ustawy, a gromadzone środki są przechowywane na osobnym koncie bankowym, którego dysponentem jest odpowiedni minister lub inny organ wskazany w ustawie. Przychody funduszy organizowane są ze środków państwowych i wydatkowane na określone cele publiczne, a zmiany w ich planach finansowych nie mogą być dokonywane na niekorzyść budżetu publicznego (por. art. 29).

2 Przepisy tej ustawy przestały obowiązywać 18 lipca $1991 \mathrm{r}$. Sam fundusz został zlikwidowany na mocy przepisów ustawy z dnia 14 grudnia 1990 r. o zniesieniu i likwidacji niektórych funduszy 
stworzyć odpowiednie warunki do wszechstronnego rozwoju kultury polskiej. W otwartym katalogu celów cząstkowych ustawodawca wspomina o wspieraniu działalności artystycznej i funkcjonujących w tym obszarze instytucji, dotowaniu muzeów, bibliotek, domów i ośrodków upowszechniania kultury, wspomaganiu kinematografii, wspieraniu badań naukowych oraz działań inwestycyjnych, edukacyjnych i promujących polską kulturę zagranicą. Struktura Funduszu Rozwoju Kultury z pozoru przypominała funkcjonujący obecnie zdecentralizowany system administracji. Instrument podzielony był na wiele części usytuowanych na poziomach: centralnym, wojewódzkim, miejskim, miejsko-gminnym oraz gminnym. Faktycznie, poszczególne jego części były refinansowane ze środków ulokowanych o jeden poziom wyżej w ustalonej hierarchii. Główne więc znaczenie dla kultury i sztuki w Polsce po 1982 roku miały jedynie środki będące w dyspozycji funduszu centralnego. Katalog źródeł dochodów FRK - znów określony w ramach otwartej enumeracji - obejmował: przekazywany przez Ministra Finansów wkład pochodzący z podatków od płac w wysokości 13,6\% osiągniętych wpływów, budżetowe dotacje inwestycyjne dla instytucji, środki z Funduszu Przeciwalkoholowego w wysokości $15 \%$ jego przychodów, darowizny i zapisy - zarówno od osób fizycznych oraz prawnych, jak i przekazywane przez istniejące fundacje. Dodatkowymi dochodami były pieniądze $\mathrm{z}$ organizowanych na rzecz funduszu imprez oraz te pochodzące $\mathrm{z}$ dopłat do cen artykułów użytku kulturalnego. Rada Ministrów mogła, w ramach swoich kompetencji, dowolnie rozszerzać katalog środków, z których czerpała centralna część FRK.

Należy docenić zastosowanie w odniesieniu do niektórych źródeł finansowania funduszu, określonej procentowo stałej stawki obowiązkowo przekazywanej na realizację jego zadań. W ten sposób zabezpieczano dla kultury pewną sumę pieniędzy, która nie była zależna od politycznej koniunktury. Ustawodawca przyjął również zasadę, iż niewykorzystane w danym roku środki były automatycznie przekazywane do puli funduszy dostępnych w roku następnym. Nie bez znaczenia dla kultury była również dużo swobodniejsza procedura alokacji środków, bez konieczności dokonywania zmian budżetowych [Szulborska-Łukaszewicz, 2009: 11]. Istotą wsparcia celowego jest precyzyjne określenie finansowanych w jego ramach zadań i źródeł przychodów na ich realizację [Szołno-Koguc, 2007: 70-71]. Wobec powyższego, za istotny błąd organizacyjny należy uznać sformułowane w trybie katalogów otwartych listy celów cząstkowych i źródeł finansowania instrumentu. Fundusz Rozwoju Kultury egzemplifikował istotną wadę genetyczną, która w polskim systemie finansowania celowego reprodukowana jest do dziś.

(Dz.U. 1990, nr 89, poz. 517), a środki zgromadzone na jego koncie przekazano specjalnie do tego celu powołanej fundacji. 


\section{Finansowanie celowe po 1989 roku — kazus Funduszu Promocji Twórczości}

W strukturze finansowania działalności kulturalnej w Polsce dominującą rolę odgrywają środki publiczne [Ilczuk, 2012: 82-91; Szulborska-Łukaszewicz, 2012; Barański, 2015]. Zjawiska takie jak: sponsoring, mecenat czy zaangażowanie korporacyjne w sferę kultury [Kopeć, 2014] nie mają powszechnego charakteru. Bezpośrednio po transformacji ustrojowej w 1989 roku zaczęto porządkować sferę finansów publicznych. Duża część parabudżetów, w tym funduszy celowych i środków specjalnych, uległa likwidacji z uwagi na potrzebę ,racjonalizacji gospodarowania środkami publicznymi" [Szołno-Koguc, 2007: 146]. Gospodarkę funduszową w obszarze kultury również dotknęła restrukturyzacja. Obecnie w dyspozycji Ministra Kultury i Dziedzictwa Narodowego pozostaje zaledwie jeden instrument celowy - Fundusz Promocji Kultury.

Po nowelizacji ustawy z dnia 4 lutego 1994 r. o prawie autorskim i prawach pokrewnych, przeprowadzonej w 2015 roku (Dz.U. 2015, poz. 1639), w obrocie prawnym przestał istnieć przeznaczony dla artystów Fundusz Promocji Twórczości - zwany potocznie Funduszem Martwej Ręki. Źródłami jego przychodów były: opłaty przekazywane przez producentów i wydawców utworów, do których autorskie prawa majątkowe wygasły, uiszczane na podstawie zasady domaine public payant [Tezy Funduszu..., 2013: 3]. Ich wysokość oscylowała w granicach od $5 \%$ do $8 \%$ wpływów brutto ze sprzedaży egzemplarzy utworów objętych daniną (Dz.U. 2003, nr 41, poz. 354; art. 40 ust. 1). Tożsame zobowiązania wobec FPT ponosili producenci i wydawcy opracowań utworów niepodlegających ochronie prawnoautorskiej. Przychody mogły także stanowić wpływy za naruszenia praw autorskich i pokrewnych oraz dobrowolne zapisy i darowizny (zob. tabela 1).

Tabela 1

Zrealizowane przychody i wydatki Funduszu Promocji Twórczości w latach 2012-2015

\begin{tabular}{|l|c|c|c|c|c|c|c|c|}
\hline \multirow{2}{*}{$\begin{array}{l}\text { Przychody } \\
\text { i wydatki } \\
\text { FPT } \\
\text { w tys. zł }\end{array}$} & \multicolumn{2}{|c|}{2012} & \multicolumn{2}{c|}{2013} & \multicolumn{2}{c|}{2014} & \multicolumn{2}{c|}{2015} \\
\cline { 2 - 8 } & przychody & wydatki & przychody & wydatki & przychody & wydatki & przychody & wydatki \\
\cline { 2 - 8 } & 525 & 406 & 1003 & 520 & 742 & 520 & 704 & 2015 \\
\hline
\end{tabular}

Źródło: Sprawozdanie..., 2012-2015.

Środki funduszu miały pokrywać koszty: stypendiów twórczych, dopłat do wydań utworów o szczególnym znaczeniu dla kultury i nauki polskiej - w tym wydań dla niewidomych, a także zapomóg dla artystów pozostających w trudnej sytuacji materialnej. Pieniądze na poszczególne cele rozdzielała ministerialna komisja, po zasięgnięciu opinii właściwych stowarzyszeń twórczych. 
Wiele zmian w funkcjonowaniu Funduszu Martwej Ręki zaproponowali Dorota Ilczuk i Wojciech Misiag. Uczeni postulowali obniżenie stawki daniny wpłacanej na rzecz FPT i ustalenie jej na jednorodnym poziomie 4\% lub zastosowanie pomniejszonego przedziału w granicach od 3\% do 5\%. Pomniejszenie takie miało być przyczynkiem do akceptacji obciążeń fiskalnych i zwiększenia ściągalności opłat [Ilczuk, Misiąg, 2003: 184]. Ostatecznie dla wszystkich podmiotów została ustalona jednolita stawka na poziomie $5 \%$. Badacze zaproponowali także wprowadzenie sankcji za uchylanie się od płatności na rzecz funduszu - łącząc tę propozycję z dolegliwością zakazu ubiegania się o dotacje ze środków publicznych. Pojawił się również pomysł ścisłego powiązania instrumentu celowego z sektorem książki, a w szczególności z systemem finansowania bibliotek publicznych. Uczeni proponowali zatrudnienie podmiotu komercyjnego do pobierania i egzekwowania należności na rzecz FPT [Ilczuk, Misiąg, 2003: 185] lub utworzenie swoistej rady sztuki, której podstawowym zadaniem miała być fachowa dystrybucja środków finansowych - z zastrzeżeniem, iż Minister Kultury i Dziedzictwa Narodowego powinien zachować prawo do ostatecznej decyzji w kwestii angażowania środków publicznych.

Za słuszne należy uznać postulaty zmierzające do ograniczenia celów czą̧stkowych instrumentu celowego i powiązanie ich wyłącznie z sektorem książki oraz te dotyczące poprawy ściągalności danin należnych funduszowi. Mocno dyskusyjny był natomiast pomysł zmierzający do implementacji zasady przedłużonego ramienia. Wyodrębnianie osobnego ciała - komercyjnego czy też publiczno-prywatnego aby dokonywać procedury dystrybucji środków czy ściągania należności mogłoby znacząco zwiększyć koszty obsługi funduszu, a tym samym uszczuplić jego i tak niewielki budżet. Co więcej, jak wynika z doświadczeń zagranicznych [Gordon-Nesbitt, 2009] oraz rodzimych badań [Lewandowska, 2017], arm's length principle nie gwarantuje bezstronności i nie zwiększa transparentności w procesie dystrybucji środków publicznych.

Istotne były również błędy wynikające z mało precyzyjnych przepisów prawa. Coroczne problemy w prognozowaniu wysokości przychodów uniemożliwiały sformułowanie jasnych zasad podziału środków między poszczególne cele cząstkowe [Tezy Funduszu..., 2013: 4]. Ustawodawca zobowiązywał się choćby do finansowania wydań dla osób niewidomych, nie określając równocześnie w eksplicytny sposób, jakie środki zapewnić należy na realizację tego zadania [Ilczuk, Misiąg, 2003: 185]. Sama nazwa funduszu celowego wskazywała w głównej mierze na komponent promocyjny w odniesieniu do polskiej kultury, tymczasem środki wspomagały wyłącznie publikacje dzieł znanych i cenionych, co w znacznym stopniu ograniczało dostęp do nich młodym, początkującym artystom, którzy rzeczywiście promocji potrzebowali. Najpoważniejszym błędem było jednak umieszczenie w katalogu zadań środka celowego zapomóg dla twórców w trudnej sytuacji materialnej czy zdrowotnej - dodać należy, że był to jedyny środek pomocy przeznaczony bezpośrednio dla artystów [Tezy Funduszu..., 2013: 4]. Prekariat z wyboru lub konieczności - pozostający poza instytucjonalnym, etatowym obiegiem zatrudnienia był skazany na nieustanną, projektową nadaktywność [Kunst, 2016: 120-136], a jednocześnie nie mógł liczyć na miejsce w publicznym systemie 
zabezpieczeń emerytalnych czy zdrowotnych. System zapomóg gwarantowanych przez Fundusz Promocji Twórczości stanowił jedynie środek doraźnej pomocy, nie zaś kompleksowe rozwiązanie systemowe, które pozwoliłoby odpowiedzieć na realne problemy środowiska artystycznego [Górna i in., 2015; Ilczuk i in., 2015; Szulborska-Łukaszewicz, 2015; Szreder, 2016]. Ujawnia się w tym miejscu patologiczna skłonność do wykorzystywania trybu finansowania celowego do maskowania problemów wymagających systemowych rozwiązań.

Od 2013 roku podejmowane były próby nowelizacji ustawy prawnoautorskiej; postulowano wówczas zmianę struktury budżetu FPT. Zakładano przeniesienie obciążeń fiskalnych z tytułu daniny domaine public payant na twórców chcących korzystać z utworów osieroconych - idea ta rzeczywiście była słuszna i znalazła swoje rozwinięcie w nowelizacji z 2015 roku, lecz nie mogła w znaczący sposób zwiększyć przychodów funduszu. Pomysł realnej restrukturyzacji budżetu FPT mógł zostać oparty na wprowadzeniu obligatoryjnych opłat za naruszenia praw autorskich, które w części lub w całości trafiałyby do budżetu środka celowego.

\section{Fundusz Promocji Kultury}

Na podstawie ustawy o grach hazardowych (Dz.U. 2009, nr 201, poz. 1540 ze zm.) został utworzony Fundusz Promocji Kultury, w jego dyspozycji pozostaje część środków pochodzących $\mathrm{z}$ dopłat do stawek w grach losowych stanowiących monopol państwa. Model wspomagania finansowego kultury za pomocą środków loteryjnych jest pomysłem brytyjskim ${ }^{3}$. Całość dopłat rozdzielana jest $\mathrm{z}$ użyciem ustalonego mechanizmu procentowego i wspiera cztery różne instrumenty celowe. Największa część, bo aż 75\% wszystkich środków uzyskanych z loterii i gier, przekazywana jest na działalność Funduszu Rozwoju Kultury Fizycznej. $Z$ dopłat w wysokości $20 \%$ korzysta kultura (zob. tabela 2).

Tabela 2

Zrealizowane przychody i wydatki Funduszu Promocji Kultury w latach 2013-2017

\begin{tabular}{|l|c|c|c|c|c|c|c|c|}
\hline $\begin{array}{l}\text { Przychody } \\
\text { i wydatki } \\
\text { FPK } \\
\text { w tys. zł }\end{array}$ & \multicolumn{2}{|c|}{2014} & \multicolumn{2}{c|}{2015} & \multicolumn{2}{c|}{2016} & \multicolumn{2}{c|}{2017} \\
\cline { 2 - 9 } & przychody & wydatki & przychody & wydatki & przychody & wydatki & przychody & wydatki \\
\cline { 2 - 9 } & 159716 & 165872 & 196634 & 154606 & 201481 & 175352 & 194637 & 198715 \\
\hline
\end{tabular}

Źródło: Sprawozdanie..., 2014-2017.

${ }^{3}$ Loteria brytyjska [2018] przeznacza swoje granty na sześć szczytnych dziedzin: sztukę, dziedzictwo narodowe, zdrowie publiczne, edukację, działalność społeczną i dobroczynną oraz ochronę środowiska. Loteria zaczęła funkcjonować w 1995 roku. 
Reszta środków pozostaje natomiast w dyspozycji Funduszu Rozwiązywania Problemów Hazardowych (1\%) oraz Funduszu Wspierania Rozwoju Społeczeństwa Obywatelskiego (4\%). Fundusz Promocji Kultury ma skupiać się na dofinansowaniu między innymi: przedsięwzięć artystycznych o charakterze ogólnopolskim i międzynarodowym, czytelnictwa (szczególnie przez subsydia dla czasopism kulturalnych i niskonakładowej literatury) oraz działań związanych z ochroną dziedzictwa narodowego. Środki FPK stanowią również zabezpieczenie dla realizowanych projektów inwestycyjnych oraz wieloletnich zobowiązań zaciągniętych przez państwowe instytucje kultury. Ustawa przewiduje także przekazywanie przynajmniej 5\% corocznych przychodów funduszu na działalność Polskiego Instytutu Sztuki Filmowej. Wspomniana już nowelizacja prawa autorskiego z 2015 roku zabowiązała FPK do wspierania socjalnego artystów. $\mathrm{Z}$ listy zobowiązań funduszu zniknęły natomiast zadania związane z zapewnianiem równego dostępu do kultury osobom z niepełnosprawnościami. Środki FPK rozdzielane są zgodnie z rozporządzeniem Ministra Kultury i Dziedzictwa Narodowego, który ustala jego treść w porozumieniu z Ministrem Finansów (Dz.U. 2017, poz. 1808 ze zm.).

Fundusz Promocji Kultury jest przykładem środka celowego, który reprodukuje wszystkie błędy organizacyjno-zarządcze wskazane wcześniej. Jego podstawowym mankamentem jest zbyt daleko idąca wielokierunkowość w obrębie celów cząstkowych. Oprócz swoich pierwotnych zobowiązań przejął on również część tych wynikających z nowelizacji ustawy prawnoautorskiej. Mowa tu więc nie tylko o kwestiach zapomóg dla artystów, ale również o finansowaniu wynagrodzeń dla autorów książek wypożyczanych z bibliotek publicznych. Ta głęboka niespójność celów, nawet przy relatywnie wysokich dochodach funduszu, może być przeciwskuteczna dla idei finansowania celowego. Najprostszym rozwiązaniem wskazanego problemu byłoby ograniczenie celów cząstkowych i wybranie takich, dla których dotacje w obowiązującej perspektywie mogłyby mieć skuteczne oddziaływanie. Tutaj natomiast zaobserwować można wzrost listy zobowiązań, którego nie równoważy komplementarny wzrost po stronie przychodów. Sposobem na zwiększenie tych ostatnich mogłaby być renegocjacja stosunków procentowych przy podziale dopłat do stawek w grach losowych lub też zwiększenie samej daniny i przeznaczenie zdobytych w tym trybie środków na cele związane z kulturą. Badania przeprowadzone przez Dorotę Ilczuk i Wojciecha Misiąga [2003: 175] dowodzą, że nawet zwiększenie dopłat do stawek w grach losowych nie spowodowałoby znaczącego spadku popytu. Warto zastanowić się również, czy fundusze celowe, których żywot - jak pokazuje praktyka - jest dość niepewny, powinny być źródłem zabezpieczeń dla wieloletnich zobowiązań finansowych oraz prowadzonych inwestycji. Funkcjonowanie pojedynczego instrumentu celowego, którego lista zobowiązań ma zupełnie przypadkowy charakter, każe myśleć, że finansowanie celowe w Polsce to instrument doraźnego reagowania na istotne problemy, które nie doczekały się systemowych rozwiązań. 


\section{Fundusze celowe na kulturę w Holandii ${ }^{4}$}

Projektując zestaw zmian w funkcjonowaniu rodzimej gospodarki funduszowej, prócz refleksji krytycznej poświęconej tradycji celowego wspierania kultury w samej Polsce, warto zwrócić uwagę na dobre praktyki realizowane zagranica - w tym przypadku w Holandii. Celem tej refleksji nie jest dokonanie analizy komparatystycznej wielkości budżetów na kulturę obu krajów, a jedynie porównanie narzędzi i mechanizmów, w ramach których środki te funkcjonują. Zdecydowałem się nie podawać wysokości przychodów poszczególnych instrumentów, a jedynie zwrócić uwagę na łączny ich budżet, który w latach 2013-2016 wyniósł $133 \mathrm{mln}$ euro [Ministry of Education Culture and Science, 2013]. Celowe finansowanie kultury odbywa się w Holandii za pomocą sześciu specjalnych funduszy stworzonych z myślą o konkretnych priorytetach. Stanowią one zarazem jeden $\mathrm{z}$ trzech podstawowych filarów polityki kulturalnej w Niderlandach ${ }^{5}$.

Fonds voor de Podiumkunsten wspiera działania z zakresu sztuk performatywnych: teatr, taniec i operę, ale też zjawiska z zakresu muzyki czy festiwale. Fundusz udziela dofinansowania w ramach dwóch programów: czteroletniego wsparcia dla poszczególnych artystów oraz instytucji lub dwuletnich dotacji z przeznaczeniem na działania o charakterze projektowym. Szczególne znaczenie podczas oceny przyszłych beneficjentów mają takie wyznaczniki jak: międzynarodowy charakter planowanych działań, pielęgnowanie różnorodności kulturowej i promowanie idei przedsiębiorczości środowisk twórczych. Wspólnym mianownikiem wszystkich finansowanych przez fundusz działań jest ich przedstawieniowy charakter, nie ma tu więc mowy o jakiejkolwiek niezgodności celów cząstkowych. Twórcy mają możliwość wyboru, czy chcą realizować długofalowe przedsięwzięcia, czy też działać projektowo. Premiowanie przedsiębiorczych projektów o charakterze międzynarodowym buduje natomiast trwałe powiązania pomiędzy światem sztuki a wymogami, które stawia wolny i zglobalizowany rynek.

Fonds voor Cultuurparticipatie zapewnia środki na realizację trzech programów promujących uczestnictwo w kulturze. Największą pulę pieniędzy holenderski rząd przeznacza na podniesienie jakości edukacji kulturalnej. Dotowane są także pomysły realizowane przez artystów amatorów. W ramach ostatniego programu natomiast rząd wspiera młode talenty i nowo powstałe inicjatywy

${ }^{4}$ (1) Informacje odnośnie do celów poszczególnych funduszy funkcjonujących w Holandii podaję za: Hamersveld, Woersem, Oosterhuis, 2015; (2) Informacje dotyczące bieżącej perspektywy finansowej (2017-2020) [Leden, 2018].

${ }^{5}$ Pozostałe dwa to: (1) Sieć 84 instytucji zajmujących się kulturą i sztuką, tzw. The Basic National Infrastructure. Skupia ona podmioty o istotnym znaczeniu dla kultury narodowej oraz te, które odgrywają ważną rolę na poziomie regionalnym i miejskim. Wszystkie zrzeszone w obrębie sieci instytucje finansowane są bezpośrednio z budżetu państwa. (2) System programów Ministerstwa Edukacji Kultury i Nauki, powstających we współpracy ze stroną społeczną, biznesową oraz innymi resortami holenderskiego rządu i jednostkami samorządowymi. Obecnie funkcjonujące programy skupiają się w głównej mierze na kwestiach edukacji, partycypacji obywateli w kulturze, a także rozwoju przedsiębiorczości [Ministry of Education Culture and Science, 2013]. 
o charakterze kulturalnym. Choć instrument ten posiada kilka celów cząstkowych, to wszystkie one są powiązane ze sobą w sposób przyczynowo-skutkowy. Rząd nie tylko inwestuje w edukację - formalną i nieformalną - obywateli, ale partycypuje również w kosztach ich debiutów artystycznych i managerskich.

Mondriaan Fonds odpowiada za popularyzację sztuk wizualnych - „Fundusz stanowi finansowe wsparcie we wszystkich obszarach, w których nie są jeszcze sprawne mechanizmy rynkowe" [Hamersveld, Woersem, Oosterhuis, 2015]. W ramach tego środka celowego funkcjonuje specjalny program zakupów dzieł sztuki, prowadzony przez rząd wraz ze stoma krajowymi galeriami. Instytucje oraz prywatni nabywcy mogą pozwolić sobie na kupno artefaktów na preferencyjnych warunkach i spłacanie zaciągniętych zobowiązań w systemie ratalnym. W tym konkretnym przypadku to pieniądze publiczne stymulują popyt na rynku sztuki. W ten sposób za pieniądze z budżetu państwa budowana jest społeczna odpowiedzialność za sztukę, która realizuje się nie tylko w skali makro (przedsiębiorstwa, instytucje), ale również mikro (indywidualni nabywcy).

Od 2013 roku działa w Holandii środek celowy wspierający przemysły kreatywne-Stimulerings fonds. Jego powołanie jest wynikiem współpracy trzech resortów: Ministerstwa Spraw Zagranicznych, Ministerstwa Finansów oraz Ministerstwa Edukacji, Kultury i Nauki. W ramach tego mechanizmu granty przydzielane są w trzech kategoriach. Pierwsza z nich odnosi się do innowacji w podejściu do architektury, rozwiązań urbanistycznych, designu, mody i rozwoju kultury cyfrowej. W drugim priorytecie doceniane są innowacje wytworzone we współpracy między różnymi sektorami. Trzeci filar finansowy wspiera rozwój przedsiębiorczości w obszarze przemysłów kreatywnych. Jest to pionierski fundusz, gdyż za cel obrał sobie subsydiowanie działań w obszarze przemysłów kultury i sektora kreatywnego, których zarówno potencjał rozwoju, jak i łączne kapitały zgromadzone w poszczególnych branżach są ogromne ${ }^{6}$.

W Holandii został utworzony również osobny fundusz celowy wspierający kinematografię - Nederlands Film fonds. Podstawowe zadania tego instrumentu są związane $\mathrm{z}$ dofinansowywaniem produkcji i dystrybucji rodzimych utworów filmowych przy zachowaniu ich zróżnicowania gatunkowego. W ramach funduszu funkcjonują trzy programy. Osobno wspierani są młodzi twórcy, którzy mogą starać się o dofinansowanie ze środków priorytetu cząstkowego New Screen NL. W jego ramach finansowane są dzieła eksperymentalne i krótkometrażowe animacje. Priorytet Screen NL odpowiada za dofinansowanie filmów dokumentalnych oraz pełnometrażowych. Screen NL Plus natomiast zajmuje się kwestiami promowania holenderskiej kinematografii, dystrybucji filmów zagranicą i pozyskiwania widowni dla rodzimych produkcji.

Nederlands Letterenfonds zajmuje się rynkiem książki oraz promocją rodzimej literatury poza granicami kraju. Fundusz wspiera dziedzictwo językowe Holandii przez promocję oraz tłumaczenie na języki obce publikacji pisanych po fryzyjsku. Ze względu na postępującą cyfryzację twórczość literacka i wydawnicza

6 W Polsce do przemysłów kultury i sektora kreatywnego od 2017 roku jest kierowany jeden z programów Ministra Kultury i Dziedzictwa Narodowego [Rozwój sektorów..., 2017]. 
zasługuje na wsparcie i promocję, dlatego też, podobnie jak w przypadku kinematografii, rząd holenderski zdecydował się wyodrębnić środki z przeznaczeniem wyłącznie na rozwój książki i wspieranie związanych z nią twórców - pisarzy, tłumaczy i rysowników.

Holenderski rząd uczynił z finansowania celowego jeden z filarów swojej polityki kulturalnej. Sześć instrumentów stworzyło przemyślane narzędzie systemowego wsparcia kultury i sztuki w jej różnorodnych przejawach. Podstawową motywacją do tworzenia parabudżetów w Polsce - jeszcze w okresie PRL-u - była mniej restrykcyjna procedura rozporządzania finansami publicznymi. Po transformacji ustrojowej potencjał gospodarki funduszowej został całkowicie zmarnowany - jedyną metodą ich restrukturyzacji była właściwie likwidacja. Priorytety instrumentów holenderskich charakteryzuje wysoki stopień specjalizacji połączony z komplementarnością w zakresie realizowanych celów cząstkowych. Lista zobowiązań Funduszu Promocji Kultury jest nie tylko zbyt szeroka, lecz także mało koherentna. Holendrzy rewidują założenia swojej polityki kulturalnej co cztery lata, co daje realną możliwość reagowania na zmiany potrzeb środowiska kulturalnego. Ustawodawca w Polsce nie ustalił cyklicznego trybu rewizji listy celów FPK ani procentowego mechanizmu podziału środków pomiędzy poszczególne priorytety cząstkowe. Holenderskie środki zostały wykorzystane do wspierania obszarów kultury, które nie licują z wolnorynkowymi obostrzeniami, oraz po to, by stymulować rozwój intratnych przemysłów kultury i sektora kreatywnego. W Polsce zaś fundusze celowe są dowodem eskapistycznej strategii działania państwa, które zamiast proponować systemowe rozwiązania istotnych problemów - zabezpieczenia socjalnego i emerytalnego artystów, zapewnienia środków na obsługę zadłużeń instytucji kultury oraz prowadzonych inwestycjiucieka się do rozwiązań doraźnych.

\section{Zakończenie - propozycje zmian}

Analiza polskich doświadczeń w zakresie celowego finansowania kultury, pogłębiona o refleksję nad rozwiązaniami holenderskimi, dowodzi, że rodzima praktyka organizacyjno-zarządcza wymaga przynajmniej kilku istotnych korekt. W pierwszej kolejności zalecać należy głęboką restrukturyzację Funduszu Promocji Kultury i włączenie części jego przychodów do budżetów innych instrumentów publicznego finansowania. Środki takie mogłyby zasilić budżety sieci instytucji o charakterze narodowym, wokół których ogniskują się konkretne branże polskiego środowiska kulturalnego. Takie rozwiązanie sugeruje nawet obecna struktura budżetu funduszu - przynajmniej 5\% przychodu FPK trafia co roku na konto Polskiego Instytutu Sztuki Filmowej. W tym momencie część pieniędzy jest redystrybuowana w ramach tzw. Programów Ministra, których operatorami są właśnie wspomniane instytucje. Podział całości dostępnych środków pomiędzy instytuty branżowe spowodowałby ich realną specjalizację, oddalenie decyzji o alokacji pieniędzy od politycznego ośrodka oraz 
pozwoliłby wykorzystać potencjał ekspercki tkwiący w samych instytutach. Zadania środków celowych powinny podlegać strategicznemu planowaniu i podążać za rzeczywistymi potrzebami ich odbiorców. Warto pomyśleć więc nie tylko o odpowiednim uszczupleniu listy zobowiązań funduszu, ale o wprowadzeniu cyklicznej procedury rewizji jego celów cząstkowych. Z listy zadań FPK muszą zniknąć priorytety, które domagają się systemowych rozwiązań. Mam tu na myśli w pierwszej kolejności uregulowanie statusu zawodowego artysty, a co za tym idzie kwestii zabezpieczeń emerytalnych, rentowych i zdrowotnych. Pomóc w tym może refleksja nad rozwiązaniami stosowanymi zagranicą [Ilczuk, 2017].

Równie istotne co twarda restrukturyzacja są zmiany miękkie. Należy rekomendować położenie większego nacisku na realizację priorytetów w międzysektorowym porozumieniu i wspieranie ruchów klastrowych zmierzających do łączenie kultury z nauką, przemysłem czy biznesem. Zadbać trzeba również o utrzymanie prawidłowego balansu między finansowaniem intratnych obszarów kultury i tych, które nie radzą sobie jeszcze zbyt dobrze na wolnym rynku. W przypadku funduszy celowych niezbędne jest ich rozważne konstruowanie oraz dbałość, aby gromadzone na ich kontach środki były wydawane efektywnie. Zaproponowane rozwiązania mogą pomóc w ograniczeniu chaotycznych i, co paradoksalne, zupełnie bezcelowych posunięć organizacyjno-zarządczych.

\section{Bibliografia}

\section{Akty prawne}

Rozporządzenie Ministra Kultury i Dziedzictwa Narodowego z dnia 27 września 2017 r. w sprawie szczegółowych warunków uzyskiwania dofinansowania realizacji zadań z zakresu kultury, trybu składania wniosków oraz przekazywania środków z Funduszu Promocji Kultury, Dz.U. 2017, poz. 1808 ze zm.

Ustawa z dnia 4 maja 1982 r. o Narodowej Radzie Kultury oraz Funduszu Rozwoju Kultury, Dz.U. 1982, nr 14, poz. 111 ze zm.

Ustawa z dnia 14 grudnia 1990 r. o zniesieniu i likwidacji niektórych funduszy, Dz.U. 1990, nr 89, poz. 517.

Ustawa z dnia 4 lutego 1994 r. o prawie autorskim i prawach pokrewnych, Dz.U. 1994, nr 24, poz. 83 ze zm.

Ustawa z dnia 27 sierpnia 2009 r. o finansach publicznych, Dz.U. 2009, nr 157, poz. 1240 ze $\mathrm{zm}$.

Ustawa z dnia 19 listopada 2009 r. o grach hazardowych, Dz.U. 2009, nr 201, poz. 1540 ze zm.

Ustawa z dnia 11 września 2015 r. o zmianie ustawy o prawie autorskim i prawach pokrewnych oraz ustawy o grach hazardowych, Dz.U. 2015, poz. 1639. 


\section{Literatura}

Barański R. (2015), Finansowanie działalności kulturalnej, C.H. Beck, Warszawa.

Gordon-Nesbitt R. (2009), Gniew to siła, tłum. M. Nowicka [w:] K. Chmielewska, K. Szreder, T. Żukowski (red.), Czytanki dla robotników sztuki. Kultura nie dla zysku, z. 1, Fundacja Bęc Zmiana, Warszawa.

Górna K. i in. (red.) (2015), Czarna księga polskich artystów, Wydawnictwo Krytyki Politycznej, Warszawa.

Hamersveld I. van, Woersem L. van, Oosterhuis R. (2015), Cultural Policy Profile: The Netherlands, http:/www.culturalpolicies.net/web/netherlands.php?aid=812 [dostęp: 1.05.2015].

Ilczuk D. (2012), Ekonomika kultury, Wydawnictwo Naukowe PWN, Warszawa.

Ilczuk D. (2017), Wsparcie dla twórców i artystów. Perspektywa międzynarodowa, http:// www.nck.pl/badania/raporty/raport-wsparcie-dla-tworcow-i-artystow-perspektywa-miedzynarodowa [dostęp: 15.04.2018].

Ilczuk D., Misiąg W. (2003), Finansowanie i organizowanie kultury w gospodarce rynkowej, Instytut Badań nad Gospodarką Rynkową, Warszawa.

Ilczuk D., Dudzik T., Gruszka E., Jeran A. (red.) (2015), Artyści na rynku pracy, Attyka, Kraków.

Kietlińska K. (1995), Finansowanie kultury dylematy teorii i praktyki, Wydawnictwo Uniwersytetu Łódzkiego, Łódź.

Kopeć K.D. (2014), Finansowanie kultury w ramach społecznej odpowiedzialności biznesu, Libron - Filip Lohner, Kraków.

Kunst B. (2016), Artysta w pracy. O pokrewieństwie sztuki i kapitalizmu, tłum. P. Sobaś-Mikołajczyk, D. Gajewska, J. Jopek, Instytut Teatralny im. Zbigniewa Raszewskiego i in., Warszawa-Lublin.

Leden J. van der (2018), Cultural Policy Profile: The Netherlands, http://www.culturalpolicies.net/down/netherlands_112016.pdf [dostęp: 1.03.2018].

Lewandowska K. (2017), Sfera autonomii, sfera biurokracji. Relacje polskich teatrów publicznych $i$ ich organizatorów $w$ perspektywie międzynarodowej, „Zarządzanie w Kulturze", 3 (18).

Loteria brytyjska (2018), https://www.national-lottery.co.uk [dostęp: 15.03.2018].

Ministry of Education Culture and Science (2013), The Dutch Cultural System, http://www. government.nl/documents-and-publications/leaflets/2013/06/17/the-dutch-cultural-system.html [dostęp: 1.03.2018].

Sprawozdanie z wykonania budżetu państwa w części 24 i dziale 921 - Kultura i Ochrona Dziedzictwa Narodowego(2012), Ministerstwo Kultury iDziedzictwa Narodowego, Warszawa, http://www.mkidn.gov.pl/pages/strona-glowna/ministerstwo/budzet-ministerstwa.php [dostęp: 15.03.2018].

Sprawozdanie z wykonania budżetu państwa w części 24 i dziale 921 - Kultura i Ochrona Dziedzictwa Narodowego (2013), Ministerstwo Kultury i Dziedzictwa Narodowego, Warszawa, http://www.mkidn.gov.pl/pages/strona-glowna/ministerstwo/budzet-ministerstwa.php [dostęp: 15.03.2018].

Sprawozdanie z wykonania budżetu państwa w części 24 i dziale 921 - Kultura i Ochrona Dziedzictwa Narodowego (2014), Ministerstwo Kultury i Dziedzictwa Narodowego, Warszawa, 
http://www.mkidn.gov.pl/pages/strona-glowna/ministerstwo/budzet-ministerstwa.php [dostęp: 15.03.2018].

Sprawozdanie z wykonania budżetu państwa w części 24 i dziale 921 - Kultura i Ochrona Dziedzictwa Narodowego (2015), Ministerstwo Kultury i Dziedzictwa, Warszawa. Narodowego, http://www.mkidn.gov.pl/pages/strona-glowna/ministerstwo/budzet-ministerstwa.php [dostęp: 15.03.2018].

Sprawozdanie z wykonania budżetu państwa w części 24 i dziale 921 - Kultura i Ochrona Dziedzictwa Narodowego (2016), Ministerstwo Kultury i Dziedzictwa Narodowego, Warszawa, http://www.mkidn.gov.pl/pages/strona-glowna/ministerstwo/budzet-ministerstwa.php [dostęp: 15.03.2018].

Sprawozdanie z wykonania budżetu państwa w części 24 i dziale 921 - Kultura i Ochrona Dziedzictwa Narodowego (2017), Ministerstwo Kultury i Dziedzictwa Narodowego, Warszawa, http://www.mkidn.gov.pl/media/docs/budzet/20180711Sprawozdanie_z_wykonania_budzetu_cz_24_i_dzialu_921_-_KiODN_za_2017r.pdf [dostęp: 20.02.2019].

Szołno-Koguc J. (2007), Funkcjonowanie funduszy celowych w Polsce w świetle zasad racjonalnego gospodarowania środkami publicznymi, Wydawnictwo Uniwersytetu Marii Curie-Skłodowskiej, Lublin.

Szreder K. (2016), ABC projektariatu. O nędzy projektowego życia, Fundacja Bęc Zmiana Warszawa.

Szulborska-Łukaszewicz J. (2009), Polityka kulturalna w Krakowie, Attyka, Kraków.

Szulborska-Łukaszewicz J. (2012), Instytucje kultury w Polsce - specyfika ich organizacji i finansowania, „Zarządzanie w Kulturze”, 4 (13).

Szulborska-Łukaszewicz J. (2015), Artysto scen polskich, powiedz nam, z czego żyjesz, ZASP - Stowarzyszenie Polskich Artystów Teatru, Filmu, Radia i Telewizji, Kraków.

Tezy Funduszu Promocji Twórczości poszukiwanie alternatywnych źródel finansowania (2013), Ministerstwo Kultury i Dziedzictwa Narodowego, Warszawa, http://www.prawoautorskie.gov.pl/media/drugie_forum_/Tezy_Fundusz_Promocji_Tworczosci.pdf (2018) [dostęp: 15.03.2018]. 
